\title{
THE IMPORTANCE OF ESTABLISHING FUNCTIONAL POSITION OF CORPORATE SUPERVISOR AT THE MINISTRY OF LAW AND HUMAN RIGHTS
}

\author{
Jamilus \\ Research and Development Board for Law and Human Rights, \\ the Ministry of Law and Human Rights of the Republic of Indonesia Jakarta \\ Corresponding email: djamilus57@gmail.com
}

Paper received on: 03-03-2021; Revised on: 06-05-2021; Approved to be published on: 06-05-2021

DOI: http://dx.doi.org/10.30641/dejure.2021.V21.175-186

\begin{abstract}
The establishment of Functional Position of Corporate Supervisor is one of the priority working programs to be realized at the Directorate General of Legal Administrative Affairs. This is important, not only to implement the government programs, namely simplifying the bureaucracy, but also to optimize the performance of the Ministry of Law and Human Rights. The question is why it is important to establish the Functional Position of Corporate Supervisor at the Ministry of Law and Human Rights. The research method used is normative and empirical legal research with descriptive research characteristics and a qualitative analysis approach. The results showed that the importance of the Functional Position of Corporate Supervisor at the Ministry of Law and Human Rights is based on the mandate of Presidential Regulation Number 13 Year 2018 and Article 138 to Article 141 of Law Number 40 Year 2007, as well as changes in the institutional structure of the Directorate of Civil Affairs. In order for the mandate of Presidential Regulation Number 13 Year 2018 and Article 138 to Article 141 of Law Number 40 Year 2007 to be realized, the Ministry of Law and Human Rights needs to immediately establish the Functional Position of Corporate Supervisor, and also immediately change the organizational structure of the Directorate of Civil Affairs.
\end{abstract}

Keyword: Functional Position of Corporate Supervisor at the Ministry of Law and Human Rights

\section{INTRODUCTION}

In accordance with Presidential Regulation Number 68 Year 2019 concerning the Organization of State Ministries, the Ministry of Law and Human Rights is tasked with assisting the President in carrying out state governance in the field of law, laws and regulations, legal administrative affairs, correctional institution, immigration, intellectual property and human rights.

However, in carrying out its duties and functions, the bureaucratic process sometimes still requires quite a long time, for example in terms of services for proposing the establishment of a Limited Liability Company, in its implementation the service must go through a tiered procedure, starting from the lowest level to the higher level.

In a state speech, President Joko Widodo then asked for bureaucratic reform aimed at creating a professional State Civil Apparatus (ASN) with expertise and competence. The President has also mandated structural reforms, so that institutions will be simpler and more agile.

Therefore, plans to cut several structural positions at the echelon 3 and echelon 4 levels and transfer employees to functional positions were announced $^{1}$. All of these policies are intended to create efficiency and effectiveness of a more dynamic bureaucracy.

In the roadmap for structuring organizational units, it is said that structural reforms are carried out by (1) mapping and analyzing the tasks and functions of echelon III downwards; (2) Preparing transfer criteria; (3) Equalizing functional position allowance; (4) Inpassing (adjusting) functional position that has been established; (5) Establishing new functional positions; and (6) Transferring to a newly established functional position ${ }^{2}$.

Therefore, to carry out professional services and pay attention to the structural reform, the Directorate General of Legal Administrative Affairs of the Ministry of Law and Human Rights in 2020 announced the establishment of Functional Position of Corporate Supervisor, as is the existence of Functional Position of Civil Curator,

\footnotetext{
"Https://News.Detik.Com/Berita/d- 4753220/ Pidato - Lengkap - Jokowi- Usai- Dilantik-JadiPresiden-Ri-2019-2024/3," https://news.detik.com/ berita/d-4753220/pidato-lengkap-jokowi-usaidilantik-jadi-presiden-ri-2019-2024/3.

2 Kementerian Pendayagunaan Aparatur Sipil Negara Dan Reformasi Birokrasi, Grand Design Reformasi Birokrasi 2010-2025, n.d.
} 
Functional Position of Civil Servant Investigator, Functional Position of Notary Analysis, and Functional Position of Dactyloscopy ${ }^{3}$.

The Functional Position of Corporate Supervisor has become a very basic need and is a position that shows the duties, responsibilities, authority and rights of a state civil apparatus in an organizational unit which in carrying out its duties is based on certain expertise and skills, especially supervision of the principle of recognizing beneficial owner. In addition, the Functional Position of Corporate Supervisor is a demand to provide convenience to doing business in Indonesia which is currently the obligation of the stakeholders.

In addition, the establishment of the Functional Position of Corporate Supervisor is also important considering that the public service duties assigned to the Directorate General of Legal Administrative Affairs have become increasingly complex with the existence of new authority. For example, an order to verify cooperatives legalization as mandated by Regulation of Minister of Law and Human Rights Number 14 Year 2019 concerning Cooperatives Legalization; Order to accept Limited Partnership, Firm, and civil partnership registration as mandated by Regulation of Minister of Law and Human Rights Number 17 Year 2018 concerning Registration of Limited Partnership, Firm, and Civil Partnership; then the supervisory order mandated by Presidential Regulation Number 13 Year 2018 concerning the Implementation of the Know-YourBeneficial-Owner Principle by Corporations for the Prevention and Eradication of Criminal Acts of Money Laundering and Terrorism Financing (Presidential Regulation 13/2018); there is also an order for supervision of company data in the list of companies as mandated by Article 29 of Law Number 40 Year 2007 concerning Limited Liability Companies (Law 40/2007).

Not to mention that the Sub-Directorate of Legal Entity also does a lot of work outside the existing duties and functions ${ }^{4}$. For example,

\footnotetext{
"Direktorat Jenderal Administrasi Hukum Umum, 'Ini Pesan Yasonna di Raker Ditjen AHU', 2020,” (portal. ahu.go.id/id/detail/75-berita-lainnya/2468-ini-pesanyasonna-di-raker-ditjen-ahu) diakses pada 2 Februari 2021

4 Data diperoleh melalui kuesioner dengan Kasubdit Badan Hukum via daring, pada tanggal 5 Juni 2020
}

analyzing legal issues related to private companies and receiving complaints and consultations regarding name of company, legalization of Limited Liability Company, approval of changes to articles of association of Limited Liability Company, notification of amendments to articles of association and notification of changes to company data of limited liability company, etc.

From the aforesaid tasks, up to now, there are 2 (two) supervision that has not been implemented optimally by the Sub-Directorate of Legal Entity of the Directorate of Civil Affairs. This is due to the lack of excellent and professional Human Resources (HR) who have specific skills and competencies in carrying out these tasks.

The Indonesian government itself has actually enacted Law Number 5 Year 2014 concerning State Civil Apparatus which mandates reform in the field of human resource management for public sector, starting from the recruitment process, appointment, promotion, transfer, to dismissal of employee. The entire series of government apparatus management reform is carried out by prioritizing the principle of merit and is expected to boost the professionalism of State Civil Apparatus in carrying out their function as public policy implementer, public servant, as well as unifier of the nation.

That is why the establishment of Functional Position of Corporate Supervisor at the Ministry of Law and Human Rights is already urgent in nature, this needs to be done for the effectiveness of the performance and obedience of the surrounding organization. However, to what extent are the constraints and bureaucratic impacts on these institutions.

Based on this description, the question in this paper is, why is it important to establish Functional Position of Corporate Supervisor at the Ministry of Law and Human Rights?

\section{RESEARCH METHOD}

The method used in this paper is juridical normative based on literature research and empirical juridical research, by using secondary and primary data in the field of law. Secondary data consists of books, literature, scientific paper magazines, materials from the internet that are 
related to and support this writing 5 . Meanwhile, the primary data in this research covers the laws and regulations related to the establishment of the Functional Position of Corporate Supervisor. As for juridical empirical research by looking at the practice in the field through interview method with related parties, in this case the Officials of the Directorate General of Legal Administrative Affairs, especially the structural officers of Directorate of Civil Affairs, Sub-directorate of Legal Entity, who carry out supervision/ verification of corporations. The nature of this research is descriptive analytical, because through this paper it is hoped that a systematic and factual description of existing legal data will be obtained.

\section{DISCUSSION AND ANALYSIS}

To find out and analyze why it is important to establish Functional Position of Corporate Supervisor at the Ministry of Law and Human Rights, the researcher will highlight from the regulatory aspect which has given the authority to the Ministry of Law and Human Rights, in this case the Directorate General of Legal Administrative Affairs to carry out supervisory/inspection duties on corporations, namely: Presidential Regulation Number 13 Year 2018 concerning Implementation of the Know-Your-Beneficial-Owner Principle by Corporations for the Prevention and Eradication of Criminal Acts of Money Laundering and Terrorism Financing and Law Number 40 Year 2007 concerning Limited Liability Company (in particular Article 138 to Article 141), and from the aspect of institutional structure, this is done to answer the position of the institution after the issuance of the aforesaid Law and how it will impact on the continuation of the existing structure.

\section{Presidential Regulation Number 13 Year 2018}

The Presidential Regulation Number 13/2018 was issued with the consideration that money laundering and terrorism financing criminal acts can threaten the stability and integrity of the economic system and the financial system. Then in the field of prevention and eradication of money laundering and terrorism financing criminal acts, it is necessary to have arrangements

\footnotetext{
5 Sugiyono, Metode Penelitian Kuantitatif, Kualitatif Dan RED (Bandung: CV.Alfabeta, 2017).
}

and mechanisms to identify the beneficial owner of a corporation. In addition, corporations can be used as a means, either directly or indirectly, by criminal offenders who are the beneficial owners of the proceeds of money laundering and terrorism financing criminal acts, which so far have not been regulated.

Article 1 number 3 of the Presidential Decree Number 13/2018 explains the definition of an Authorized Institution as follows: Authorized Institution is a government agency both at the central and regional levels that has the authority to register, ratify, approve, notify, permit business, or dissolve a corporation, or an institution that has the authority to supervise and regulate business field of Corporation.

Article 13 Paragraph (1) states that in addition to the Beneficial Owner that has been determined by the Corporation as referred to in Article 3, the Authorized Institution can determine another Beneficial Owner. Furthermore, Paragraph (3) explains that the government institutions which have the authority to determine other beneficial owners and of course to conduct supervision are:

a. The ministry that administers government affairs in the field of law for limited liability companies, foundations and associations;

b. The ministry that administers government affairs in the field of cooperatives and small and medium enterprises for cooperatives;

c. The ministry that administers government affairs in the field of trade for limited partnership, firm partnership, and other corporate forms; and

d. Institution that has the authority to supervise and regulate business field of Corporation.

In accordance with the mandate given by Presidential Regulation Number 13/2018, that the Ministry of Law and Human Rights, in this case the Directorate of Civil Affairs, has been given the authority to supervise the beneficial owner of a corporation. This is as stated in CHAPTER IV Article 23 Paragraph (1) of Presidential Regulation Number 13 Year 2018 which states that "supervision of the implementation of the knowyour-beneficial owner principle shall be carried out by an Authorized Institution". Then what is meant by authorized institution according to Article 1 number 3 of the aforesaid Presidential Regulation is government institution both at the 
central and regional levels that have the authority to register, ratify, approve, notify, permit business, or dissolve a corporation, or an Institution that has the authority to supervise and regulate business field of corporation.

The authority to supervise in question is as follows ${ }^{6}$ : to establish regulations or guidelines for implementing this Presidential Regulation in accordance with their authority; to conduct audit of a corporation; and to carry out other administrative activities within the scope of duties and responsibilities in accordance with the provisions of this Presidential Regulation.

Furthermore, Article 23 of the aforesaid Presidential Regulation explains that in carrying out supervision, the authorized institution shall collaborate with the Financial Transaction Reports and Analysis Center, and if necessary can coordinate with related institutions in accordance with their authority.

Then Article 24 emphasizes the sanctions, it states that Corporations that do not implement the provisions referred to in Article 3, Article 14, and Article 18 to Article 22 are subject to sanctions in accordance with the provisions of laws and regulations.

To carry out this supervision, the Ministry of Law and Human Rights in 2019 issued Regulation of the Minister of Law and Human Rights Number 21 Year 2019 concerning Procedures for Supervising the Know-Your-Beneficial-Owner Principle by Corporations, as the implementing regulations of the Presidential Regulation Number 13 Year 2018, where the purpose of this supervision is to confirm the true beneficial owner and to prevent the misuse of corporation as a holding center for funds for the purpose of terrorism and money laundering crimes.

Article 1 number 3 has defined that supervision is an activity for the purpose of assessing and/or ensuring the compliance of a corporation in fulfilling the provisions of the Know-Your-Beneficial-Owner Principle by Corporations.

\footnotetext{
6 Lihat Pasal 23 ayat (2) Peraturan Presiden Nomor 13 Tahun 2018 tentang Penerapan Prinsip Mengenali Pemilik Manfaat Dalama rangka pencegahan dan Pemberantasan Tindak Pidana Pencucian Uang dan Tindak Pidana Pendanaan Terorisme
}

Article 2 Paragraph (2) then states that corporation as referred to in Paragraph (1) includes:

a. limited liability company;

b. foundation;

c. association;

d. cooperatives;

e. limited partnership;

f. firm partnership; and

g. other forms of corporation.

The determination of beneficial owner of a corporation as referred to in Paragraph (1) shall be carried out by the corporation through the implementation of the Know-Your-BeneficialOwner Principle by Corporations. And the procedure for implementing the Know-YourBeneficial-Owner Principle by Corporations shall be carried out in accordance with the provisions of the prevailing laws and regulations.

Supervision of the implementation of the Know-Your-Beneficial-Owner Principle by Corporations shall be carried out by the Minister through the Director General of Legal Administrative Affairs. Furthermore, Article 3 Paragraph (2) states that the supervision can be carried out in the form of:

a. establishing regulations or guidelines as the implementation of laws and regulations regarding the implementation of the KnowYour-Beneficial-Owner Principle by Corporations;

b. performing an audit of corporation;

c. performing other administrative activities within the scope of duties and responsibilities in accordance with the provisions of laws and regulations regarding the implementation of the Know-Your-Beneficial-Owner Principle by Corporations.

Meanwhile Paragraph (3) states that in carrying out the supervision as referred to in Paragraph (1), the Directorate General of Legal Administrative Affairs shall coordinate with related institutions in accordance with their authority. However, these three things have not been carried out by the authorized institutions, especially the Sub-directorate of Legal Entity, because the progress of drafting guidelines as the implementation of Presidential Regulation Number 13 Year 2018 is still waiting for the 
preparation of a standard risk assessment from the Financial Transaction Reports and Analysis Center. The guideline will measure corporations with low, medium and high risk levels, which also refers to the National Risk Assessment.

\section{STAGES OF SUPERVISION}

The supervision shall be carried out through the following stages (Article 5 Paragraph (1)):

a. Filling out a questionnaire by the corporation;

b. Risk assessment of money laundering and terrorism financing criminal acts against corporations;

c. Implementation of supervision in accordance with the risk level; and

d. Implementation of recommendations by the Corporation.

The stages of supervision as referred to in Paragraph (1) letter a and letter $b$ shall be carried out electronically and non-electronically on the online Legal Administrative Affairs. Meanwhile, the stages of supervision as referred to in paragraph (1) letters $c$ and d shall be carried out electronically and non-electronically on the online Legal Administrative Affairs.

\section{IMPLEMENTATION OF SUPERVISION}

According to Article 8, in carrying out the supervision as referred to in Article 3, the Minister shall perform:
a. Indirect supervision (off-site)
b. Direct supervision (on-site).

The indirect supervision is carried out electronically through the online Legal Administrative Affairs, on corporations with low and medium risk levels.

The implementation of indirect supervision includes:
a. Document and information checking;
b. Assessment of the application of the Know-Your-Beneficial-Owner Principle by Corporations; and
c. Information on the results of indirect supervision

\section{Article 10.}

The direct supervision on corporations with high and very level of risk shall be carried out through:

a. Verification of documents and information;

b. Verification of information on the determination of beneficial owner of the corporation;

c. Report of the authorized institution and the related institution;

d. The process of granting business license from the authorized institution;

e. Summons of the corporation; and

f. Preparation of results of the direct supervision.

With the issuance of Regulation of Minister of Law and Human Rights Number 21 Year 2019, the supervision of the Know-Your-BeneficialOwner Principle by Corporations should have been able to be performed. However, according to the result of a research by the Research and Development Board for Law and Human Rights in 2020 , the supervision of the reporting of beneficial owner has not been implemented optimally by the Directorate General of Legal Administrative Affairs, especially by the Sub-directorate of Legal Entity ${ }^{7}$, because it requires professional officials in carrying out this task, with excellent Human Resources (HR) which shall be placed in the right position and have specific competencies.

According to the data from the execution of National Strategy of Corruption Eradication Commission of Ministry of Law and Human Rights Number B09 which was sampled from the research report by the Research and Development Board for Law and Human Rights in 2019, data is obtained as in the following table which explains that the total number of corporations is $1,461,223$ while the corporations that have filled Beneficial Ownership (BO) report or the actual beneficial owner of corporation are only 58,743 while 1,402,480 corporation have not reported BO yet. Corporate data since the promulgation of Presidential Regulation Number 13 Year 2018 (March 5, 2018 to October 4, 2019) is as follows8:

7 Jamilus, dkk Pembentukan Jabatan Fungsional Pengawas Korporasi Di DIrektorat Jenderal AHU Kementerian Hukum Dan HAM (Balitbangkumham Press, 2020).

8 Nevey Varida Ariani,dkk Laporan Hasil Penelitian 
Table: Number of Corporation

\begin{tabular}{|l|l|l|l|l|}
\hline Corporation & $\begin{array}{c}\text { Number of } \\
\text { Corporation }\end{array}$ & $\begin{array}{l}\text { Have filled } \\
\text { BO report }\end{array}$ & $\begin{array}{c}\text { Did not } \\
\text { declare }\end{array}$ & $\begin{array}{c}\text { Percentage } \\
\mathbf{( \% )}\end{array}$ \\
\hline $\begin{array}{l}\text { Limited } \\
\text { Liability } \\
\text { Company }\end{array}$ & 923,037 & 28,327 & 894,710 & $3.06 \%$ \\
\hline Association & 164,827 & 1,976 & 162,851 & $1.19 \%$ \\
\hline Foundation & 212,660 & 3,212 & 209,448 & $1.51 \%$ \\
\hline $\begin{array}{l}\text { Limited } \\
\text { Partnership }\end{array}$ & 157,672 & 24,831 & 132,841 & $15.74 \%$ \\
\hline Firm & 1,258 & 181 & 1,077 & $14.38 \%$ \\
\hline $\begin{array}{l}\text { Civil } \\
\text { Partnership }\end{array}$ & 1,769 & 216 & 1,553 & $12.21 \%$ \\
\hline Total & $1,461,223$ & 58,743 & $1,402,480$ & \\
\hline
\end{tabular}

Source: Report of execution of National Strategy

of Corruption Eradication Commission of Ministry

of Law and Human Rights Number B09 http:/jaga.

$\mathrm{id} /$ monitoring

Based on the research report, it can be seen that there are still many corporations that have not submitted information related to their beneficial owners. Finding out the actual beneficial owners in a corporation is not easy. Because according to a study conducted by the Corruption Eradication Commission, the absence of information on Beneficial Owner (BO) in the context of law enforcement causes difficulties in knowing or tracking down the actual owners who receive benefits from a company. If the company is used to commit illegal acts, the main party (BO) may enjoy the results of illegal acts, and it is also difficult to know/detect, and tax evasion is very likely to occur' ${ }^{9}$. Therefore, it requires a Functional Official of Corporate Supervisor who has certain expertise and competence to carry out the task.

The duties of Functional Position of Corporate Supervisor in relation to the Know-YourBeneficial-Owner Principle by Corporations shall be carried out in accordance with the provisions of Article 3 Paragraph (2) of Regulation of Minister of Law and Human Rights as previously explained.

Furthermore, the supervision of the implementation of the Know-Your-BeneficialOwner Principle by Corporations includes:

a. application of identification and verification of information on Beneficial Owner of a corporation;

Penerapan Beneficial Owner Dalam Pencegahan Dan Pemberantasan Tindak Pidana Pencucian Uang, 2019.

9 file:///C:/Users/User/Documents/Kegiatan\%2o tahun\%202019/Penelitian\%20BO/Beneficial\%20 Ownership\%20-\%2oKajian\%2oI\%2oKPK.pdf, di akses 3 Februari 2021 b. determination of Beneficial Owner of corporation;

c. Submission of information on beneficial owner of a corporation to the Ministry which administers government affairs in the field of law and human rights;

d. Submission of changes to information on Beneficial Owner of a corporation;

e. Update of information on Beneficial Owner of a corporation;

f. Administration of documents of Beneficial Owner of a corporation; and

g. Appointment of corporate officers or employees in the context of implementing Beneficial Owner of Corporation.

\section{Law Number 40 Year 2007}

Furthermore, the supervision/examination of Limited Liability Companies as mandated by Article 138 to 141 of Law Number 40 Year 2007 concerning Limited Liability Companies (UU PT) states that the examination of companies can be carried out with the aim of obtaining data or information if there is a suspicion that ${ }^{10}$ :

1) The company has committed an unlawful act that is detrimental to shareholders or third parties.

2) A member of the Board of Directors or the Board of Commissioners has committed an unlawful act that is detrimental to the Company or shareholders or third parties.

The applicant may submit a request for examination of the Company if the applicant has requested directly to the Company for the data or information that he/she needs, but the Company refuses or does not pay attention to the request. The application for the examination of the Company shall be made by submitting a written application along with the reasons thereof to the District Court whose jurisdiction covers the domicile of the Company.

The application for the examination of the Company can be submitted by ${ }^{11}$ :

a. 1 (one) or more shareholders who represent at least $1 / 10$ (one tenth) of the total shares with voting rights.

\footnotetext{
10 Lihat Pasal 138 ayat (1) Undang-Undang Nomor 40 tahun 2007 tentang Perseroan Terbatas

"Ibid Pasal 138 ayat (3)
} 
b. Other parties who, based on laws and regulations, the Company's articles of association or an agreement with the Company, are authorized to submit requests for examination.

c. Office of Prosecutor General for the public interest.

Applications for examination of the Company submitted by shareholders can only be submitted after the shareholders have previously requested data or information from the Company at a General Meeting of Shareholders, but the Company does not provide such data or information.

Application for obtaining data or information about the Company or application for examination to obtain the data or information must be based on reasonable reasons and in good faith. If the application is not based on reasonable reasons and/or is not made in good faith, the Head of the District Court may reject the application.

If the District Court grants the application, the Head of the District Court will issue an examination order and appoint a maximum of 3 (three) experts to carry out the examination with the aim of obtaining the required data or information $^{12}$. The appointed expert is a person who has expertise in the field to be examined and the person appointed as an expert may not come from members of the Board of Directors, members of the Board of Commissioners, employees of the Company, consultants, and public accountants who have been appointed by the Company.

Expert who has been appointed by the Head of the District Court has the right to examine all documents and assets of the Company which are deemed necessary to be known. Each member of the Board of Directors, members of the Board of Commissioners and all employees of the Company are required to provide all information necessary for the examination. Expert who has been appointed is obliged to keep the results of the examination that has been carried out secret.

The report on the results of the examination shall be submitted by the expert to the Head of the District Court within a period of no later than 90 (ninety) days from the date of the appointment of the expert ${ }^{13}$. Then the Head of the District Court shall give a copy of the examination result report to

\footnotetext{
12 Ibid Pasal 139 ayat (3)

13 Ibid Pasal 140 ayat (1)
}

the applicant and the Company concerned within a period of no later than 14 (fourteen) days from the date the examination result report is received ${ }^{14}$.

The court shall determine the amount of examination fee based on the level of expertise of the examiner and the limit of the capacity of the Company and the scope of the Company. The examination fee shall be paid by the Company, but the Head of the District Court at the request of the Company may charge the full or partial compensation of the examination fee to the applicant, members of the Board of Directors and/ or members of the Board of Commissioners ${ }^{15}$.

The examination of a limited liability company can be carried out by Functional Position of Corporate Supervisor with the following arguments:

a. Functional Position of Corporate Supervisor can be declared as an expert with evidence of a training certificate in the field of corporate law which is his/her expertise.

b. The Law of Limited Liability Company is the scope of duties that fall under the authority of the Ministry of Law and Human Rights which is carried out by the Sub-directorate of Legal Entity, Directorate of Civil Affairs, Directorate General of Legal Administrative Affairs.

c. As an effort to enforce the rules of Law of Limited Liability Company in order to provide legal certainty and legal protection to the society.

The two regulations have not been implemented so far. This is because the task of supervision/examination has a high level of difficulty, so that supervisors who have certain expertise and skills are needed, especially the supervision mandated by Presidential Regulation Number 13/2018 concerning the Know-YourBeneficial-Owner Principle by Corporations. What is meant by expert here is someone who has mastered a certain knowledge so that he/she becomes an expert in his/her field ${ }^{16}$. With the expertise possessed, it is hoped that they will be able to achieve the objectives of supervision,

14 Ibid Pasal 140 ayat (2)

15 Ibid Pasal 141 ayat (3)

16 Jamilus, "Optimalisasi Mediasi Kekayaan Intelektual Di Kemenkumham," Jurnal Penelitian Hukum De Jure Vol.20. No.1 (2020): 43 . 
namely as said by the Director of Civil Affairs in a public discussion related to the Establishment of Functional Position of Corporate Supervisor at the Ministry of Law and Human Rights in Tangerang on October 20, 2020 $0^{17}$, that is not only to confirm the actual beneficial owner, but everything that happens to the corporation must be supervised, including the finance to find out the beneficial owner in the corporation. And no less important is to prevent the misuse of corporations as a holding center for funds for the purpose of terrorism and money laundering crimes. Because today, corporations are not only synonymous with the civil realm, but their actions may be related to the criminal realm. Like the Nazarudin case, where he was not directly registered as a leader or administrator in a Permai Group company, but he was able to control the company and gain the most benefit by disguising and hiding the origin of the assets obtained from corrupt practices ${ }^{18}$. And according to Yunus Husein ${ }^{19}$, someone can be categorized as a beneficial owner if he/she gains profits, but those who are registered as shareholders in the company are his/her family members.

That is one example of a beneficial owner case that has occurred in Indonesia. For this reason, it is hoped that the Functional official of Corporate Supervisor with their authority will be able to play a role in preventing the misuse of a corporation.

Then the Functional Position of Corporate Supervisor can be categorized as expertise functional position because the implementation of their duties is based on a science that has methodology and analysis technique as well as audit work procedures in corporate law and capital market law using the Legal Audit methodology with due diligence analysis technique as has been done with the establishment and amendment of the Articles of Association of Corporation which

\footnotetext{
${ }_{17}$ "Jft-Korporasi-Di-Bahas-Direktur-Perdata-IniMendukung-Pengawasan-Prinsip-MengenaliPemilik-Manfaat-Beneficial-Ownership-Bo."

18 https:// www. slideshare. net/ pw ypindonesia/ pengungkapan-beneficial-ownership-di-indonesiamenutup-celah-korupsi-untuk-perbaikan-tata-kelola, di akses pada tanggal 8 April 2021.

19 h t t p s : / / n a s i o n a l. k o m pa s . c o m / $\mathrm{read} / 2018 / 03 / 13 / 09485451 /$ beneficial-owner-setyanovanto-ahli-pakai-contoh-nazaruddin, di akses pada tanggal 8 April 2021\%oA\%oA.
}

is the scope of duties of the Sub-Directorate of Legal Entity so far.

In addition, according to the results of the Research and Development Board for Law and Human Rights research in $2020^{20}$, the Functional Position of Corporate Supervisor at the Ministry of Law and Human Rights can be established up to the level of Senior Expert, this determination is based on the high level of difficulty in carrying out the supervisory task, especially in supervising beneficial owner in a corporation.

Likewise, the supervision/examination of Limited Liability Company as mandated by Article 138 to 141 of Law Number 40 Year 2007 concerning Limited Liability Company (UU PT). If a Limited Liability Company violates the provisions of the articles as mentioned above, the duties of an expert can be carried out by the Functional Official of Corporate Supervisor, because the Ministry of Law and Human Rights is given the authority to do so.

Furthermore, Human Resources (HR) currently in the Sub-directorate of Legal Entity are approximately 30 (thirty) people consisting of various scientific backgrounds ${ }^{21}$. With this number of human resources, to supervise thousands of corporations throughout Indonesia is very lacking, however, for the initial stage of the establishment of the Functional Position of Corporate Supervisor this number is deemed sufficient, it is just that the competence of each employee needs to be added with knowledge in other disciplines such as civil law, capital market, investment, bankruptcy and banking.

However, the authority mandated by the two rules above have yet to be implemented until now, because these tasks as described above must be carried out by functional officials who have competence and expertise in the corporate sector. The human resources to carry out the supervision are technically ready to wait for the regulations for the establishment of the Functional Position. Therefore, the establishment of Functional Position of Corporate Supervisor is urgently needed at the Ministry of Law and Human Rights, especially in the Directorate of Civil Affairs.

\footnotetext{
20 Jamilus, Pembentukan Jabatan Fungsional Pengawas Korporasi Di DIrektorat Jenderal AHU Kementerian Hukum Dan HAM hlm. 90.

${ }^{21} \quad$ Ibid hlm. 3.
} 


\section{Institutional structure}

So far, those who carry out the task of examining files through the database of the Legal Entity Administration System (SABH) and the Business Entity Administration System (SABU) via online systems through the Legal Administrative Affairs Online application (such as: registration and dissolution of Limited Liability Company, registration of cooperatives, registration of Limited Partnership, Firm, civil association, Foundation, association) is the Subdirectorate of Legal Entity (echelon III) which oversees 4 heads of sub-sections (echelon IV), and several staff under them.

However, with this bureaucratic system, the results of the examination/analysis of a file carried out by staff do not quickly reach the leader who will make a decision, because the results of the staff's work have to go through several officials ranging from the lowest to the higher levels. With such stages, it is certainly not in accordance with what the society wants, namely the process which is quick and the results (decisions) will also be quick. In addition, it will be difficult to achieve the target of completing an application (both registration and change of name of Limited Liability Company, Limited Partnership, etc.), while the number of application files (both registration and change) that are submitted to the application of the Directorate General of Legal Administrative Affairs every day is around 1,20022.

According to the Minister of Empowerment of State Apparatus, the service with the bureaucratic system is a bureaucratic problem in Indonesia that must be solved immediately in order to realize the effective and efficient governance and be able to provide quality services. One of these problems is the unprofessional behavior of State Civil Apparatus, even though State Civil Apparatus human resources are the most important element in the bureaucracy, not only in the physical sense of employees, but regarding all aspects inherent in the employee concerned, starting from behavior, competence, knowledge, creativity or other soft skills ${ }^{23}$.

22 Data diperoleh dari pejabat Subdit Badan Hukum.

${ }_{23}$ "Ini Enam Penyakit Birokrasi Di Indonesia," https:// www.beritasatu.com/nasional/485766/ini-enampenyakit-birokrasi-di-indonesia, di akses pada tanggal 9 April 2021.
To avoid this lengthy bureaucratic process, the Functional Position of Corporate Supervisor is very appropriate to be established in the Ministry of Law and Human Rights, especially in the Directorate of Civil Affairs, where the functional official is directly responsible to the Director of Civil Affairs, this is in accordance with the Regulation of Minister of Empowerment of State Apparatus and Bureaucracy Reform Number 13 Year 2019 Article 2 which states that:

(1) Functional Officials are positioned as functional technical executors at Government Institutions.

(2) Functional Officials as referred to in Paragraph (1) are positioned under and are directly responsible to Primary High Head Officials, Administrator Officials, or Supervisory Officials who are related to the implementation of Functional Position duties.

(3) The position of Functional Officials as referred to in Paragraph (2) is determined in a job map based on the working unit's task and function analysis, job analysis and workload analysis which are carried out in accordance with the provisions of laws and regulations.

The need for Functional Position of Corporate Supervisor is in line with President Joko Widodo's speech which has given the mandate for structural reform, so that institutions become simpler and more agile. In the roadmap for structuring organizational units, it is said that structural reform is carried out by (1) mapping and analyzing the tasks and functions of echelon III downwards; (2) Preparing transfer criteria; (3) Equalizing functional position allowance; (4) Adjusting functional position that has been established; (5) Establishing new functional positions; and (6) Transferring to a newly established functional position $^{24}$.

With the order to reform the organizational structure of an institution (including the Ministry of Law and Human Rights), technically the Human Resources at the Directorate General of Legal Administrative Affairs are ready to be processed to become functional official of corporate supervisor.

\footnotetext{
24 Kementerian Pendayagunaan Aparatur Sipil Negara dan Reformassi Birokrasi, Grand Design Reformasi Birokrasi 2010-2025.
} 
With the establishment of the Functional Position of Corporate Supervisor at the Directorate of Civil Affairs, it can be ascertained that supervision that has not been able to be carried out by the Sub-directorate of Legal Entity (such as: mandate of Presidential Regulation Number 13 Year 2018 and Article 139 to Article 141 of the Law of Limited Liability Company) can be carried out by the functional official of Corporate Supervisor. Because every official who is appointed as a functional official, of course, in carrying out his/her duties he/she has met the necessary qualifications and has the competence and knowledge, not only in the corporate sector but also knowledge in other fields such as banking, bankruptcy and so on.

\section{CONCLUSION}

Whereas the importance of the Functional Position of Corporate Supervisor at the Ministry of Law and Human Rights is based on the mandate of Presidential Regulation Number 13 Year 2018 and Article 138 to Article 141 of Law Number 40 Year 2007, as well as the need to rearrange the existing institutional structure of the Directorate of Civil Affairs based on the Law in question.

\section{SUGGESTION}

In order for the mandate of Presidential Regulation Number 13 Year 2018 and Article 138 to Article 141 of Law Number 40 Year 2007 to be realized, the Ministry of Law and Human Rights needs to immediately establish Functional Position of Corporate Supervisor, and also immediately change the organizational structure of the Directorate of Civil Affairs and realize it without causing loss for the parties.

\section{ACKNOWLEDGMENT}

The researcher would like to thank the Head of the Research and Development Board for Law and Human Rights who always encouraged me in writing this scientific paper and I also would like to thank my journal management colleagues who are always loyal to help until this paper is qualified to be published in a journal of the Research and Development Board for Law and Human Rights.

\section{BIBLIOGRAPHY}

Jamilus. "Optimalisasi Mediasi Kekayaan Intelektual Di Kemenkumham." Jurnal Penelitian Hukum De Jure Vol.20. No (2020): 43.

-. Pembentukan Jabatan Fungsional Pengawas Korporasi Di DIrektorat Jenderal AHU Kementerian Hukum Dan HAM. Balitbangkumham Press, 2020.

Nevey Varida Ariani. Laporan Hasil Penelitian Penerapan Beneficial Owner Dalam Pencegahan Dan Pemberantasan Tindak Pidana Pencucian Uang, 2019.

Sugiyono. Metode Penelitian Kuantitatif, Kualitatif Dan R\&D. Bandung: CV.Alfabeta, 2017.

"Direktorat Jenderal Administrasi Hukum Umum, 'Ini Pesan Yasonna Di Raker Ditjen AHU', 2020." (portal.ahu.go.id/id/detail/75-beritalainnya/2468-ini-pesan-yasonna-di-rakerditjen-ahu) diakses pada 2 Februari 2021.

"Https://News.Detik.Com/Berita/d-4753220/ Pidato-Lengkap-Jokowi-Usai-DilantikJadi-Presiden-Ri-2019-2024/3.” https:// news.detik.com/berita/d-4753220/pidatolengkap-jokowi-usai-dilantik-jadi-presidenri-2019-2024/3.

"IniEnamPenyakitBirokrasiDiIndonesia."https:// www.beritasatu.com/nasional/485766/inienam-penyakit-birokrasi-di-indonesia, di akses pada tanggal 9 April 2021.

"Jft-Korporasi-Di-Bahas-Direktur-PerdataIni-Mendukung-Pengawasan-PrinsipMengenali-Pemilik-Manfaat-BeneficialOwnership-Bo."

Kementerian Pendayagunaan Aparatur Sipil Negara Dan Reformassi Birokrasi, Grand Design Reformasi Birokrasi 2010-2025, n.d.

"No Title." https://www.slideshare.net/ pwypindonesia/pengungkapan-beneficialownership-di-indonesia-menutup-celahkorupsi-untuk-perbaikan-tata-kelola, di akses pada tanggal 8 April 2021. 
"No Title." https://nasional.kompas.com/ $\mathrm{read} / 2018 / 03 / 13 / 09485451 /$ beneficialowner-setya-novanto-ahli-pakai-contohnazaruddin, di akses pada tanggal 8 April 2021\%0A\%0A.

Undang-Undang Nomor 5 Tahun 2014 Tentang Aparatur Sipil Negara

Undang-Undang Nomor 40 tahun 2007 tentang Perseroan Terbatas

Peraturan Pemerintah Nomor 17 Tahun 2020 tentang Perubahan Atas Peraturan Pemerintah Nomor 11 Tahun 2017 tentang Manajemen Pegawai Negeri Sipil

Peraturan Presiden Nomor 13 Tahun 2018 tentang Penerapan Prinsip Mengenali Pemilik Manfaat dari Korporasi Dalam Rangka Pencegahan dan Pemberantasan Tindak Pidana Pencucian Uang dan Tindak Pidana Pendanaan Terorisme

Peraturan Menteri Pendayagunaan Aparatur Sipil Negara dan Reformasi Birokrasi Nomor 13 Tahun 2019 tentang Jabatan Fungsional

Permenkumham Nomor 21 Tahun 2019 tentang Tata cara Pengawasan Prinsip Mengenali Pemilik Manfaat dari Korporasi 
HALAMAN KOSONG

186 | Jurnal Penelitian Hukum De Jure Vol. 21 No. 2, Juni 2021: 175-186 